\title{
Evaluation on Training Program of Integrating Character Education in Civics Education for the Teachers Learning Community
}

\author{
Fatimah \\ Universitas Lambung Mangkurat \\ Banjarmasin, Indonesia \\ imahpswunlam_21@yahoo.com
}

\begin{abstract}
The main objective of this research is to analyze the levels of reaction, teaching and learning, behavior, and results of the participants of character education training program from Teachers' Learning Community of Civics Education in Tapin Disctrict. This research used a qualitative approach based on Kirkpatrick's program evaluation model. Data were collected using the techniques of observation, interview, questionnaire and documentation. Research result showed that (1) reaction level was in the high category, (2) teaching and learning level was effective. Learning achievement obtained from the pretest and posttest results showed that there is improvement as the learning results of learning, teaching and training, (3) behavioral level was effective and very useful, because it changed the behavior in teachers' attitude, skill and knowledge, and (4) the responsibility of Civics Education teachers showed positive response as seen from their working effectiveness as the manifestation of qualities of working and creativity.
\end{abstract}

Keywords-Training, Character Education, Teachers' Learning Community (MGMP), Kirkpatrick's evaluation model

\section{INTRODUCTION}

Development Program of Teachers' Profesionality is a program of improving competences through working group, individually or in group, sustainably conducted, for management, improvement, teachers' development of knowledge and competence according to their expertise, in order to present an impact on the learning process. Implementation of sustainable development of teachers' profesionality has been conducted in the working group of MGMP (Musyawarah Guru Mata Pelajaran/ Subject Teachers' Learning Community) for junior high school (SMP/MTs) teachers and also senior high schools (SMA/SMK/MA) teachers, including teachers involved in MGMP of Civics Education; while the teachers' profesionality has been conducted in the working group of KKG (Kelompok Kerja Guru/ Teachers' Working Group).

Teachers have duties to sustainably improve their competencies as a part of the Sustainable Profesionality Development. In this relation, it is necessary to empower
KKG and MGMP as the learning communities that are very strategic for teachers' competence and their working performance. Therefore, the empowerment of KKG and MGMP must be sustainably conducted, among other things, through training, improvements of facilities and infrastructure, and managerial quality of KKG and MGMP [2].

Based on the educational policies, especially on Indonesian character education, Civics Education (PKn) have to specially integrate character values in the learning and teaching process. Character education has been conducted in a long period of time at schools, from preschool education (TK/PAUD), primary school (SD), junior high school (SMP), senior high school (SMA/SMK), special need-based school, and PKBM. SKB, as it has been conducted at the pilot school for South Kalimantan since 2010, namely the pilot school of Banjar District, but there have been many problems faced by the teachers in its implementation.

The results of interview to the teachers of Civics Education (PKn) and observation on the teaching anf learning processes of Civics Education at the VIII grade of SMP Negeri 1 Rantau with the material of globalization impact toward nation and country of Indonesia in the teaching and learning on character values such as religious, disciplinary, honest, tolerant, democratic, curious, nationalism, social and environment care, selfcontrol, responsible, and appreciative to achievement values showed that the lesson plans were not designed well based on the character values. In relation to development of learning material, the character values were not well developed. This is to say that the learning material did not present the integration of Civics Education material and relevant character values.

In relation to the case, MGMP of Civics Education of Junior High School in Tapin District conducted Training on Integration of Character Education in Learning and Teaching of Civics Education for Civics Education of Junior High Schools. The program has been running for a long time; however, research studies to examine the effectiveness of the program execution have not much conducted. Therefore, it is necessary to study how the 
reaction, teaching and learning, as well as result of integrating training execution of character education in teaching and learning of Civics Education for MGMP of Junior High Schools in Tapin district.

Theoretically Civics education refers to character education, for the charater education is in the same quality as Civics Education [8], in percieving toward crisis in society [11], motivating the learners to be appreciative, and simphatic based on values approach [4]. A part of character education taxonomy relies on Civics [9]. Character education covers Civics, and Civics education factually needs the foundation of character education [6]. In the context of Civics education, character education determines to improve civic virtue, namely: good citizenship behavior [8]. Based on the education policy, especially character education of Indonesia, Civics education must specially integrate character values in the process of teaching and learning [10].

Integrated character education in the process of teaching and learning is related to introduction to values, facilitation on how values awareness are achieved, values internalization into students' daily behavior through direct and indirect teaching and learning processes. There are two subjects that are directly related to the development of ethics and morality, namely: the subjects of Religious Education and Civics Education. These two subjects directly introduce values, and make the students have a care as well as internalize values into daily behavior through teaching and learning processes, from the steps of planning, execution, and evaluation [10].

Lesson plans are constructed based on syllabus, teaching program planning, relevant teaching material, implementation of teaching and learning processes, and evaluation based on the contextual teaching and learning principles. Implementation of the teaching and learning consists of preliminary, core, and closing activities. In addition the behavior of teachers throughout the learning process should be a model of implementation of the values for students presenting the character building through the implementation of teaching and learning.

The educational program consists of planning, implementation, and evaluation. This is to say that evaluation is a systematic process of collecting and analyzing information on the quality of education [12]. In addition, the evaluation is conducted for making decision [5], meanwhile Isaac and Michael state evaluation as a form of activity in order to see the feedback and improve continually for the sake of enlightenment, accountability, program improvement, clarification programs, program development, and symbolic reasons [5].

One of the forms of evaluation is the program evaluation. According to Joint Commette, as quoted by Brinkerhoff, that the program evaluation refers to a process of evaluation toward a program or activity [1]. Evaluation model used in this research is a Kirkpartrick's evaluation model that consists of four evaluation namely evaluation of reactions, evaluation of learning, evaluation of behavior, and evaluation of results [7]. The four levels of evaluation describe a series of ways for evaluating the programs. In relation to Kirkpatrick's model, the evaluation must be started from the first level (reaction), the second level (learning and teaching), the third level (behavior), up to the fourth level (result). Information found from each level is used as a basic line for executing the next level of evaluation. This means that each level of evaluation presents an accurate measurement of effectiveness on training and its analysis.

The main objective of this research is to analyze the levels of reaction, teaching and learning, behavior, and results of the participants of character education training program from MGMP of Civics Education in Tapin district.

\section{METHOD}

This research was designed to evaluate the training that integrated character education in the teaching and learning of civics education for the junior high schools teachers learning community in Tapin district.

The research on program evaluation of training refers to Kirkpartick's evaluation consisting of four levels of evaluation, starting from evaluation of reaction, teaching and learning, behavior, up to result/impact, with the improving orientation training program. This research used a qualitative approach. This is to say that the researcher collected qualitative data, namely: those were in the form of manuscript, narration of interview result, pictures/video taken in the process of observation, field notes, ducuments, memo, and personal documents, and also the other relevant documents to the object of the research. Quantative data were also collected in this research, such as the results of pretest-posttest, and those of questionary instrument as the initial data.

Validation of the instrument was done through the process of preparing a research instrument consulted to and guided by the promoter commission. Then, the research instrument that was constructed based on the consultation and guidance were validated by several experts to assess the suitability of the items constructed based on a framework to measure indicators of the variables to be measured and used to collect the quantitative data

Data collection techniques used in this research were observation, indepth interview, documentation, and questionnaire. Furthermore, qualitative data were validated through triangulation.

The data were qualitatively analyzed using the Miles and Huberman's data analysis technique, namely; data reduction, data presentation, conclusion drawing. Quantitative data were also justified toward the result of quantitative data analysis based on the percentage of achievement scores of assessment results obtained from comparison between empirical scores of assessment results and theoretical maximum scores [13]. In addition, analysis of quantitative data derived from the questionnaire results were presented in the tabular form of frequency and data 
interpretation, and data analysis based on justification were categorized from the evaluation results. The categorial justification of evaluation results on actuality decison making at each level of evaluation were done by measurement at each focus to be summarized in the form of matrix, and to be adapted into case-order effect matrix.

TABLE I. FEASIBILITY RESULTS OF TEACHER ACTIVITIES

\begin{tabular}{|c|c|c|c|c|}
\hline $\begin{array}{c}\text { Evaluation } \\
\text { Compo- } \\
\text { nents }\end{array}$ & $\begin{array}{c}\text { Aspects } \\
\text { evaluated }\end{array}$ & $\begin{array}{c}\text { Data } \\
\text { Sources }\end{array}$ & $\begin{array}{c}\text { Data collecting } \\
\text { techniques }\end{array}$ & $\begin{array}{c}\text { Types of } \\
\text { Instruments } \\
\text { used }\end{array}$ \\
\hline Reaction & $\begin{array}{l}\text { Initial } \\
\text { Teaching } \\
\text { Program } \\
\text { Plan } \\
\text { (RPP) and } \\
\text { Training }\end{array}$ & $\begin{array}{l}\text { Teachers } \\
\text { of Civics } \\
\text { Educatio } \\
\text { n, Head } \\
\text { Masters }\end{array}$ & $\begin{array}{l}\text { Questionnaire, } \\
\text { Interview } \\
\text { Observation } \\
\text { Documents }\end{array}$ & $\begin{array}{l}\text { List of } \\
\text { questions } \\
\text { Interview } \\
\text { guide } \\
\text { Observation } \\
\text { sheet } \\
\text { Documents }\end{array}$ \\
\hline $\begin{array}{l}\text { Learning } \\
\text { and } \\
\text { Teaching }\end{array}$ & $\begin{array}{l}\text { Knowledge, } \\
\text { attitude, and } \\
\text { skill, RPP } \\
\text { of training }\end{array}$ & $\begin{array}{l}\text { Teachers } \\
\text { of Civics } \\
\text { Education, } \\
\text { instructor }\end{array}$ & $\begin{array}{l}\text { Questionnaire, } \\
\text { Interview } \\
\text { Observation } \\
\text { Documents }\end{array}$ & $\begin{array}{l}\text { List of } \\
\text { questions } \\
\text { Interview } \\
\text { guide } \\
\text { Observation } \\
\text { sheet } \\
\text { Documents }\end{array}$ \\
\hline Behavior & $\begin{array}{l}\text { Teachers' } \\
\text { creativity } \\
\text { and } \\
\text { behavior, } \\
\text { Students' } \\
\text { behavior }\end{array}$ & $\begin{array}{l}\text { Teachers } \\
\text { of Civics } \\
\text { Education, } \\
\text { students }\end{array}$ & $\begin{array}{l}\text { Questionnaire, } \\
\text { Interview } \\
\text { Observation } \\
\text { Documents }\end{array}$ & $\begin{array}{l}\text { List of } \\
\text { questions } \\
\text { Interview } \\
\text { guide } \\
\text { Observation } \\
\text { sheet } \\
\text { Documents }\end{array}$ \\
\hline Results & $\begin{array}{l}\text { Teachers' } \\
\text { innovation, } \\
\text { RPP of } \\
\text { Civics } \\
\text { Education, } \\
\text { Having } \\
\text { characters, } \\
\text { Fornative } \\
\text { Test }\end{array}$ & $\begin{array}{l}\text { Teachers } \\
\text { of Civics } \\
\text { Education, } \\
\text { students }\end{array}$ & $\begin{array}{l}\text { Questionnaire, } \\
\text { Interview } \\
\text { Observation } \\
\text { Documents }\end{array}$ & $\begin{array}{l}\text { List of } \\
\text { questions } \\
\text { Interview } \\
\text { guide } \\
\text { Observation } \\
\text { sheet } \\
\text { Documents }\end{array}$ \\
\hline
\end{tabular}

The data were qualitatively analyzed using the Miles and Huberman's data analysis technique, namely; data reduction, data presentation, conclusion drawing. Quantitative data were also justified toward the result of quantitative data analysis based on the percentage of achievement scores of assessment results obtained from comparison between empirical scores of assessment results and theoretical maximum scores [13]. In addition, analysis of quantitative data derived from the questionnaire results were presented in the tabular form of frequency and data interpretation, and data analysis based on justification were categorized from the evaluation results. The categorial justification of evaluation results on actuality decison making at each level of evaluation were done by measurement at each focus to be summarized in the form of matrix, and to be adapted into case-order effect matrix.

\section{RESULTS AND DISCUSSION}

\section{A. Purpose and Target of Training}

The purpose of the training is to achieve the same perception on character education for the teachers of Civics Education of Junior High School in Tapin district to follow. Having the same perception on character education, the teachers of Civics Education will be able to maximize the improvement of insight and quality of competence, so as to become professional teachers, namely having improved knowledge, skills and attitudes as the professional teachers. The target of training is to present Civics Education teachers who have the competence, professionality, and good teaching performance. In particular, the target of training is the teachers of Civics Education of SMP / MTs in Tapin district to be educated teachers, having increasing competence, performance and professionalism.

\section{B. The Practicality of Teaching Media}

\section{1) Level of Reaction}

Evaluation of reaction level for the training participants on perception, material, instructor, means and infrastructure can be categorized as being effective and in high qualification, as can be seen in the Table II below.

TABLE II. EVALUATION OF REACTION IN TRAINING OF INTEGRATING CHARACTER EDUCATION INTO TEACHING AND LEARNING OF CIVICS EDUCATION

\begin{tabular}{|c|l|c|c|}
\hline No. & Aspect of Reaction & Score & Total Score \\
\hline 1 & Material of Training & 561 & 660 \\
\hline 2 & Training Instructor & 687 & 990 \\
\hline 3 & Training Means & 371 & 440 \\
\hline Total & 1619 & 2090 \\
\hline \multicolumn{2}{|l|}{ Percentage of Score } & $77,46 \%$ & \\
\hline
\end{tabular}

Based on the table above, the ratio of total score of the evaluation results of Civics Education teachers of SMP/MTs' reaction to total of theoretical maximum was equal to $77.46 \%$, as a percentage score was $77.46 \%$, based on quartile distribution, is above $\mathrm{Q}^{3}$; it can be justified that the result of the evaluation is in a high evaluation category. Therefore, it can be said that the participants' reaction is high.

Interview results also support the teachers' reaction. It can be seen from the statements relating to perception; "it is positively responded"; the material presented is "appropriate", " the schedule is in accordance with the execution"; instructors' presentation is "easy to understand", they are "charming and humorous"; they are "'easy in communication"; we are "comfortable to ask", "I am pleased"; we "understand"; "I am very grateful I can understand"; and the infrastructures are "adequate".

\section{2) Level of Teaching and Learning}

Evaluation on teaching and learning conducted by the training participants covers the aspects of knowledge, attitude and skill, observation toward activities of teaching and learning, documentation of teaching and 
learning after attending the training. From the aspect of knowledge, it is effective; it shows a maximum score, $86,73 \%$; attitude, $66,18 \%$; skill, $77,27 \%$. Meanwhile, the result of observation toward learning and teaching, the Civics Education teachers of Grade VII achieved the score of $86,42 \%$; those of Grade VII, $82,26 \%$, and those of Grade IX, 90,94\%. The result of observation toward teaching and learning conducted by the Civics Education teachers, viewed from the percentage achieved and based on quartile distribution, showed that the position is above $\mathrm{Q}^{3}$. Thus, it can be justified that it is in a high category. Besides, the documentation of the students' learning achievement in Civics Education showed a significant improvement, namely: $75 \%$ for Grade VII, $05,83 \%$ for Grade VII, and $61,54 \%$ for Garde IX.

The whole evaluation result of teaching and learning conducted by the training participants can be seen in Tabel III as follows.

TABLE III. EVALUATION ON LEARNING AND TEACHING OF TRAINING OF INTEGRATING CHARACTER EDUCATION IN CIVICS EDUCATION

\begin{tabular}{|c|l|c|c|}
\hline No. & Aspects of Learning and Teaching & Score & Total score \\
\hline 1 & Learning and Teaching Process & 660 & 880 \\
\hline 2 & Skill & 440 & 660 \\
\hline \multicolumn{2}{|c|}{ Total } & 1100 & 1540 \\
\hline \multicolumn{2}{|c|}{ Percentage of score } & \multicolumn{2}{|c|}{$71,43 \%$} \\
\hline
\end{tabular}

The evaluation result on the level of teaching and learning conducted by the training participants shows a theoritic maximum score total of $71,43 \%$. Referring to the quartile distribution, it can be categorized as the moderate achievement. This is because the percentage of $71,43 \%$ is below $\mathrm{Q}^{3}$. Thus, the teaching and learning conducted by the training participants is in the moderate category. This result is caused by the fact that there were some training participants who did not attend the training seriously; meanwhile, the training material, training instructors, and training equipments were sufficiently prepared. The teaching and learning have been well conducted so the changes happened just for the serious training participants.

Meanwhile, the interview result showed that the training participants could improve their knowledge. They have improved their "insight knowledge, especially in constructing Plan of Learning and Teaching Program in Charater-Based Civics Education"; they have got knowledge from the training as in the statements: "there is knowledge gotten from the training", "in the past time, we did not know Plan of Learning and Teaching Program in Charater-Based Civics Education, and now we understand it"; "we have got much knowledge from the training"; and "our knowledge have been increasing". From the aspect of attitude, there were some statements such as : "love feeling to the students becomes better", "there are creativity and innovation, and become more active", "trying to find the material via di internet", "to be impressed that character values are implemented in our own attitude and behavior", "there are changes in attitude and behavior, either as teachers or participants", "personally I think this training is useful"

From the aspect of skill; "the teachers have ability to implement it", "it is implemented throuh habit", "skill to integrate character values according to the material of Civics Education, and implementative skil in learning and teaching of Civics Education in the classroom....the next is to try implement character values in attitude and behavior for the daily activities at school, at home and in society"; "we observe their daily activties at school, we give them homework"; "it is needed the various assessments", "it is needed to assess the affective and psychomotoric aspects, other than the cognitive aspect".

\section{3) Level of Behavior}

Evaluation on the level of behavior toward the training participants covers the aspects of usefulness, attachment, and communication; the indicator is a behavioral change. The result of evaluation is presented in Table IV below.

TABLE IV. EVALUATION ON TRAINING PARTICIPANTS FOR INTEGRATING EDUCATION CHARACTER IN LEARNING AND TEACHING OF CIVICS EDUCATION

\begin{tabular}{|c|c|c|c|c|c|c|}
\hline \multirow[t]{2}{*}{ No } & \multirow{2}{*}{$\begin{array}{c}\text { Behavioral } \\
\text { Aspects }\end{array}$} & \multirow{2}{*}{$\begin{array}{c}\Sigma \\
\text { score }\end{array}$} & \multirow{2}{*}{$\begin{array}{c}\% \\
\text { maximum } \\
\text { scores }\end{array}$} & \multicolumn{3}{|c|}{ Criteria } \\
\hline & & & & Effective & $\begin{array}{c}\text { Less } \\
\text { effective }\end{array}$ & $\begin{array}{c}\text { Ineffec- } \\
\text { tive }\end{array}$ \\
\hline 1 & Usefulness & 288 & 87,27 & $\sqrt{ }$ & - & - \\
\hline 2 & $\begin{array}{l}\text { Establish- } \\
\text { ment }\end{array}$ & 475 & 86,36 & $\sqrt{ }$ & & \\
\hline 3 & $\begin{array}{l}\text { Commu- } \\
\text { nication }\end{array}$ & 465 & 84,55 & $\sqrt{ }$ & & \\
\hline 4 & $\begin{array}{l}\text { Behavioral } \\
\text { Change after } \\
\text { Training }\end{array}$ & 478 & 86,91 & $\sqrt{ }$ & & \\
\hline & Total score & 1706 & 86,27 & $\sqrt{ }$ & & \\
\hline
\end{tabular}

Evaluation result on the level of behavior toward the teachers of Civics Education showed maximum total score of $86,27 \%$. Referring to the quartile distribution, it can be categorized as a high category. This is because the percentage of score is $86,27 \%$ positioning above $\mathrm{Q}^{3}$. This can be explained that after they have attended the training and came back to their working places, they showed the changes in their attitude and behavior. At their schools, they politely behave, condusive, and are willing to share their ideas to their friends; they also try to improve tactically their mistakes; they can transfer their knowledge gotten during the training, and then implement it in their working palces, so that they can improve their working quality.

The interview result also indicated the behavioral changes, such as "character values are implemented in our own [teachers and students'] attitude and behavior", "the teachers' creativity in completing the material beyond the classroom", " the teachers have Plan of Learning and 
Teaching Program of Civics Education, and then it is implemented in Learning and Teaching Process". This condition "gradually changes in the teachers' attitude and behavior" to be able "to construct Plan of Learning and Teaching Program of Civics Education based on character values" and "to implement it in the learning and teaching process", and "its result can be written to be a scientific work". There are changes in the teachers' and the students' behavior. These changes can be seen from the facts that they "become accustomed to be low profile, polite, and respective to one and another", and one of the teachers declared "I communicate it to the teachers of other subjects".

\section{4) Level of Result/Impact}

Evaluation on the result/impact toward the training partcicipants covers the aspects of working effectiveness, working quality, and working responsibility. The evaluation result on result/impact can be seen in the Table $\mathrm{V}$ below.

TABLE V. EVALUATION OF RESULT/IMPACT ON TRAINING PARTICIPANTS IN INTEGRATING CHARACTER EDUCATION INTO LEARNING AND TEACHING OF CIVICS EDUCATION

\begin{tabular}{|l|l|c|c|c|c|c|}
\hline No & $\begin{array}{c}\text { Aspect } \\
\text { of } \\
\text { Result/ } \\
\text { Impact }\end{array}$ & $\begin{array}{c}\Sigma \\
\text { Score }\end{array}$ & $\begin{array}{c}\% \\
\text { maxi- } \\
\text { mum } \\
\text { score }\end{array}$ & $\begin{array}{c}\text { Effecti- } \\
\text { ve }\end{array}$ & $\begin{array}{c}\text { Less } \\
\text { effec } \\
\text { tive }\end{array}$ & $\begin{array}{c}\text { Ineffec- } \\
\text { tive }\end{array}$ \\
\hline 1 & $\begin{array}{l}\text { Working } \\
\text { effetive- } \\
\text { ness }\end{array}$ & 475 & 86,36 & $\sqrt{ }$ & - & - \\
\hline 2 & $\begin{array}{l}\text { Working } \\
\text { quality }\end{array}$ & 470 & 85,45 & $\sqrt{ }$ & & \\
\hline 3 & $\begin{array}{l}\text { Working } \\
\text { responsi- } \\
\text { bilty }\end{array}$ & 336 & 76,36 & $\sqrt{ }$ & & \\
\hline & $\begin{array}{l}\text { Total } \\
\text { score }\end{array}$ & 1281 & 84,55 & $\sqrt{ }$ & & \\
\hline
\end{tabular}

Evaluation on the level of result/impact toward the teachers of Civics Education shows score total of $84,55 \%$. Referring to the quartile distribution, it is categorized as the high achievement. This is because the percentage of score, $86,27 \%$, is above $\mathrm{Q}^{3}$. The indicator is the height of score and it is supported by the result of interview. The quotations of review as follows. "It is effective if it is seen from the viewpoint of result such as the Character-Based Plan of Learning and Teaching Program. The teachers are able to construct it by themselves; they are able to implement it in the classroom. Besides, they are able to be instropective toward themselves; they are aware when they give advice to the others, at the same time, they give advice to themselves. The other statements are: "Achievement of aspects of knowledge, attitudes and skills can be known after conducting the assessment of learning achievements, both learning achievement of the semester test and that for grade promotion. These three aspects can be seen in the test grating that I determined, so that I can identify the levels of difficulties of questions, distinguishing point, validity, and reliability of the tests I presented".

\section{CONCLUSIONS}

Conclusions that can be drawn from the research results are as follows:

- The effectiveness of training program of integrating character education in the teaching and learning of Civics Education for the teachers learning community in Tapin district seen from the level of reaction based on the aspects of perception, training material, training instructors, and training equipments are justified as the high category.

- The effectiveness of training program of integrating character education in the teaching and learning of Civics Education for the teachers learning community in Tapin district seen from the level of learning and teaching based on the aspects of knowledge, attitude, skill, learning and teaching process are justified as the high category. The learning achievement significantly increased. However, the overall level of the teaching and learning is justified as the moderate category.

- The effectiveness of training program of integrating character education in the teaching and learning of Civics Education for the teachers learning community in Tapin district seen from the level of behavior based the aspects of usefulness, behavioral changes, attachment, and communication are justified as the high category;

- The effectiveness of training program of integrating character education in the teaching and learning of Civics Education for the teachers learning community in Tapin district seen from the level of result/impact based on the aspects of working effectiveness, working quality, and working responsibility are justified as the high category.

\section{REFERENCES}

[1] R. O. Brinkerhoff, et al., "Program evaluation a practitioner's guide for trainers and educators," Boston: Kluwer Publishing, 1986.

[2] Dirjen PMPTK, "Rambu-rambu pengembangan KKG dan MGMP," Jakarta: Direktorat Jenderal Peningkatan Mutu Pendidik dan Tenaga Kependidikan, 2010.

[3] M. Djaali and P. Mulyono, "Pengukuran dalam bidang pendidikan,”. Jakarta: PPs-UNJ, 2000

[4] L. Gorand, S. Davies, and N. McGuinn, "Citizenship education and character education; Similarities and constrasts," British Journal of educational studies, 53 (3), 2005.

[5] N. E. Gronlund, and L. L. Robert, "Measurement and Evaluation in Teaching," New York: Macmillan Publishing, Co., 2000.

[6] J. D. Hoge, "Character education, citizenship education, and the sosial studies," The Social Studies, 93 (3), 2002.

[7] D. L.Kirkpatrick and J. D. Kirkpatrick, "Evaluating Training Program: The four Levels. San Fransisco: Library of congress Berret Kochler Publisher", Inc, 2006. 
[8] A. J. Milson and B. Chu, "Character education for cyberspace: Developing goods netizens," The Social Studies, 93 (3), 2002.

[9] L. Revell, "Children's Responses to Character Education," Educational studies, 28(4), 2002.

[10] M. Samani, and Hariyanto, "Pendidikan Karakter; Konsep dan Model," Bandung: PT. Remaja Rosdakarya, 2012.

[11] N. Silay, "Another type of character education; Citizenship education," International Journal of Education, vol. 6, No. 2, 2014.

[12] D. L. Stufflebeam and J. S. Anthony, "Evaluation: Theory, Models, \& Application," San Fransisco: Jossey-Bass, 2007.

[13] Sugiyono, "Metode Penelitian Administrasi, Making Sense Data,". Bandung: CV Alphabeta, 2002. 